\title{
STUDI TEMPORAL PERTUMBUHAN EKONOMI DAN POLUSI UDARA. STUDI KASUS: DKI JAKARTA, SEMARANG, DAN SURABAYA PADA TAHUN 2005-2015
}

\author{
Kurniawan Budi Santoso $^{I}$, Lukman Hakim ${ }^{I}$, Esya Racha Ningrum ${ }^{2}$, Wirastuti Widyatmanti ${ }^{1}$ \\ ${ }^{1}$ Prodi Kartografi dan Penginderaan Jauh,Universitas Gadjah Mada, Yogyakarta \\ ${ }^{2}$ Prodi Geografi dan Ilmu Lingkungan, Fakultas Geografi, Universitas Gadjah Mada, Yogyakarta
}

\begin{abstract}
ABSTRAK
Indonesia diproyeksikan menjadi salah satu kekuatan ekonomi yang mendominasi pasar Asia pada 2050. Namun, proses perkembangan ekonomi cenderung berdampak buruk terhadap kondisi lingkungan. Untuk itu, hubungan antara pertumbuhan ekonomi dan dampak lingkungan menjadi penting untuk dikaji sehingga pemerintah daerah dapat mengimplementasikan peraturan yang tepat sasaran pada sektor-sektor tertentu. Penelitian ini bertujuan untuk mengkaji pengaruh intensitas kegiatan ekonomi terhadap lingkungan melalui parameter Produk Domestik Regional Bruto (PDRB) sebagai parameter ekonomi dan Aerosol Optical Thickness (AOT) sebagai parameter polusi lingkungan di tiga kota besar di Indonesia yakni Jakarta, Semarang, dan Surabaya pada periode 2005-2015. Metode yang digunakan dalam penilaian hubungan tersebut adalah analisis statistik regresi. Diagram pencar hasil regresi kemudian dicocokan dengan hipotesis Environtmental Kuznet Curve (EKC). Hubungan antara PDRB dan AOT secara lebih lanjut dianalisis melalui dua pendekatan 1) Persentase kontribusi tiap sektor penyumbang PDRB; dan 2) Perubahan penggunaan lahan pada kota. Hasil menunjukkan bahwa bentuk hubungan yang terjadi pada tiga lokasi kajian adalah polynomial orde 3 dengan kecenderungan meningkat pada DKI Jakarta dan Kota Semarang serta kecenderungan menurun pada Kota Surabaya. Nilai R2 tertinggi berturut-turut ditemukan pada Kota Semarang sebesar 0.7074, DKI Jakarta sebesar 0.5223, dan Kota Surabaya sebesar 0,414. Berdasarkan hipotesis EKC diketahui bahwa perkembangan industri Kota Semarang berada pada tahap Pre-Industrial, DKI Jakarta pada tahap Industrial, dan Kota Surabaya pada tahap Post-Industrial. Hasil analisis menunjukan bahwa besaran AOT tidak hanya berkaitan dengan industri ditinjau dari nilai ekonomi yang dihasilkan, malinkan juga sektor industri yang ditinjau secara spasial.
\end{abstract}

Kata kunci: Aerosol Optical Thickness, Environtmental Kuznet Curve, Produk Domestik Regional Bruto, Industri, Penggunaan Lahan

\begin{abstract}
Indonesia is projected to be one among dominating forces in Asian market by 2050. However, the process of economic growth tends to affect the environmental conditions. Hence, the relationship between economic growth and environmental impacts becomes important to be examined so that the stakeholder could apply the best regulations. This study aims to examine the effect of the intensity of economic activity on the environment through the parameters of Gross Regional Domestic Product (GRDP) as economic parameters and Aerosol Optical Thickness (AOT) as environmental pollution parameters in three big cities in Indonesia: Jakarta, Semarang, and Surabaya during 2005 -2015. The method used in the relationship assessment is the statistical analysis of regression. The scatter diagram of the regression results is then matched with Environtmental Kuznet Curve (EKC) hypothesis. We then analyze further the relationship between GRDP and AOT using following approaches 1) Persentage contribution of each economic sector to GRDP; and 2) Land use dynamics in the cities. The result showed that the relation between AOT and PDRB in the three study sites took the $3 r d$ order polynomial form with tendency of increasing in DKI Jakarta and Semarang and decreasing in Surabaya. The highest value of $R 2$ was found in Semarang at 0.7074, DKI Jakarta at 0.5223, and Surabaya at 0.414. Based on the EKC hypothesis, it is known that industrial development of Semarang is in Pre-Industrial stage, while DKI Jakarta in Industrial stage, and Surabaya City at Post Industrial stage. The result of analysis shows that the value of AOT is not only related to the industrial sector by number of economic value, but also industrial sector viewed at spatial perspective.
\end{abstract}

Keywords: Aerosol Optical Thickness, Environtmental Kuznet Curve, Gross Regional Domestic Product, Industry, Land Use 


\section{PENDAHULUAN}

Indonesia diproyeksikan akan menjadi salah satu kekuatan ekonomi yang mendominasi pasar Asia pada 2050 selain India dan China (PwC, 2017). Perkembangan ini muncul sebagai efek dari bertumbuhnya berbagai sektor ekonomi mulai dari pertanian, perkebunan, penambangan, industri, manufaktur, hingga pelayanan jasa. Sayangnya, berbagai perkembangan sektor ekonomi tersebut diindikasikan memiliki dampak terhadap lingkungan baik pada tanah, air, maupun udara. Oleh karenanya, pertumbuhan ekonomi yang berpotensi membawa dampak lingkungan ini bukanlah hal yang bisa dilepas tangankan begitu saja tanpa adanya kontrol yang tegas.

Stern et al (1996) secara general menyatakan bahwa dampak lingkungan merupakan sebuah keniscayaan dalam perkembangan ekonomi dengan bentuk hubungan yang khas (Stern dkk., 1996). Hipotesis ini menjadi sebuah paradigma yang dikenal dengan istilah Environtmental Kuznet Curve (EKC). Akan tetapi, riset mengenai EKC ini banyak ditarik dari riset yang dilakukan pada negara-negara lintang tengah yang memiliki tren tranformasi ekonomi serta kondisi iklim yang spesifik, misalnya pada negara-negara NAFTA (Grossman dan Krueger, 1994); pada region Afrika Amerika Latin dan Asia (Cropper dan GriffXhs, 1994) ; serta pada tiga kota besar di China (Lou dkk., 2014). Sementara itu, Indonesia memiliki karakteristik pertumbuhan ekonomi, kondisi sosial, bahkan politik yang sama sekali berbeda dengan negara-negara tersebut. Hal ini secara otomatis membuat Indonesia memiliki pola degradasi lingkungan yang berbeda dengan negara-negara eropa. Menanggapi hal tersebut, riset mengenai evaluasi hubungan antara pertumbuhan ekonomi dan dampak lingkungan yang spesifik di Indonesia menjadi hal yang penting agar pemangku kebijakan dapat mengimplementasikan peraturan dan batasan yang tepat sasaran pada sektor-sektor tertentu.

Agar penelitian lebih fokus, paper ini membatasi defisini pertumbuhan ekonomi Indonesia berdasarkan data Produk Domestik Regional Bruto (PDRB) yang dianalisis pada tiga kota besar utama Indonesia yakni Jakarta, Semarang, dan Surabaya. Sementara itu, untuk melakukan kuantisasi degradasi lingkungan, kami membatasi pada lingkup polusi udara yang direpresentasikan oleh data Aerosol
Optical Thickness (AOT). Data AOT terekam pada citra MODIS level 3 (MYD09CMA) yang diterbitkan oleh NASA. Aerosol dianggap mewakili aspek polusi udara karena menurut NASA Earth Observation (2010) aerosol merupakan segala jenis partikel padat dan cair yang tersuspensi di atmosfer, termasuk debudebuan, garam laut, abu vulkanik, asap dari api, dan polusi dari pabrik. Sementara itu, AOT menyatakan derajat kemampuan aerosol dalam mencegah transmisi cahaya di atmosfer. AOT kurang dari 0.1 mengindikasikan langit cerah dengan jarak pandang maksimal, sementara nilai 4 mengindikasikan keberadaan aerosol yang padat sehingga jarak pandang buruk (NASA, 2007).

Secara garis besar, tujuan dari penelitian ini adalah untuk mengkaji besaran aerosol optical thickness di Jakarta, Semarang, dan Surabaya selama sebelas tahun serta menilai hubungan antara pertumbuhan ekonomi dan polusi udara di Jakarta, Semarang, dan Surabaya.

\section{METODE PENELITIAN}

\subsection{Sumber Data}

Data polusi udara yang digunakan dalam penelitian ini didapatkan data citra MODIS Aqua level 3 (MYD09CMA) sebagai data aerosol optical thickness (AOT) yang merupakan nilai representatif dari polusi udara. MODIS Aqua Level 3 produk 3 MYD09CMA diunduh dari situs http://ladsweb.modaps.eosdis.nasa.gov/ secara gratis. Nilai pixel yang terkandung dalam citra tersebut adalah berupa integer 16-bit. Ia memiliki faktor skala 1000 dimana nilai 0 sama dengan 0 dan 3000 sama dengan 1. Nilai AOT tahunan pada suatu wilayah diperoleh melalui rerata nilai pixel pada citra yang diunduh satu scene tiap bulan pada satu batas administrasi kota. Nilai rerata AOT dikumpulkan selama 11 tahun dari Januari 2005 hingga Desember 2015.

Sementara itu, data pertumbuhan ekonomi direpresentasikan oleh nilai Produk Domestik Regional Bruto (PDRB) atas dasar harga berlaku di DKI Jakarta, Surabaya, dan Semarang. Data didapatkan melalui publikasi dokumen Produk Domestik Regional Bruto Kabupaten-Kota di Indonesia Periode 20002003, 2003-2007, 2008-2012, dan 2012-2016 pada website Badan Pusat Statistik (BPS) (http://bps.go.id). Sementara itu, data persentase kontribusi sektor ekonomi pada PDRB juga digunakan dalam paper ini untuk 
menjelaskan kegiatan-kegiatan yang berpotensi mempengaruhi jumlah emisi polusi ke lingkungan. Data tersebut didapatkan dari website BPS Jakarta (http://jakarta.bps.go,id), BPS Surabaya (http://surabaya.bps.go,id), serta BPS Semarang (http://semarang.bps.go.id). Kami juga menggunakan data perubahan luasan kawasan industri dari 2005 hingga 2015 melalui interpretasi visual kenampakan citra yang dihimpun oleh Google Earth. Kawasan industri diidentifikasi melalui warna, tekstur, bentuk, ukuran, dan pola sehingga didapatkan poligonpoligon yang merepresentasikan kawasan industri di DKI Jakarta, Semarang, dan Surabaya.

\subsection{Analisis Regresi}

Analisis regresi linier, kuadratik, logaritmik, power, dan exponensial dilakukan untuk menguji adanya hubungan positif atau negatif antara konsentrasi AOT dan nilai PDRB tiga kota besar di Indonesia. Asumsi yang digunakan dalam penelitian ini adalah pertumbuhan ekonomi berpengaruh terhadap polusi udara karena dominasi pertumbuhan ekonomi yang diakibatkan oleh berbagai kegiatan yang menyebabkan polusi udara contohnya industri, manufaktur, dan pertambangan.

Sehingga variabel dependen yang digunakan adalah nilai AOT dari citra MODIS dan variabel independen adalah PDRB kota besar di Indonesia. Analisis regresi yang digunakan menggunakan persamaan model regresi yaitu:

$\begin{array}{ll}\text { Polynomial } & : y=a x^{2}+b x+c \\ \text { Exponential } & : y=a b^{x} \\ \text { Logaritmik } & : y=a \ln (x)+b \\ \text { Linier } & : y=a x+b \\ \text { Power } & : y=a x^{b} \\ \text { Keterangan } & : \\ \text { y } & : \text { variabel terikat } \\ \text { x } & : \text { variabel bebas } \\ \text { a, b } & : \text { konstanta }\end{array}$

Analisis ini menghasilkan nilai determinasi atau nilai $\mathrm{R}^{2}$ menunjukkan proporsi sumbangan variabel independen terhadap variabel dependen. Nilai $\mathrm{R}^{2}$ memiliki rentang 0 hingga 1. Semakin tinggi nilai $\mathrm{R}^{2}$ maka semakin besar pula variasi dari variabel independen yang dapat dijelaskan oleh variabel dependen. Kami memilih model regresi terbaik dengan membandingan nilai determinasi setiap hasil regresi pada tiap jenis regresi untuk mengetahui bentuk hubungan pada tiap kota.

\subsection{Environtmental Kuznet Curve (EKC)}

Untuk membandingkan tingkat perkembangan ekonomi tiga kota besar di Indonesia, kami menggunakan rasio konsentrasi AOT tahunan terhadap PDRB (AOT/PDRB) dihitung dari tahun ke tahun untuk masing masing kota. Selanjutnya, garis tren plot rasio dibuat untuk menggambarkan variasi perkembangan selama tahun 2005 sampai 2015. Kami kemudian mencoba mencocokan grefik tren dengan environtmental kuznet curve (EKC) untuk melihat apakah ada kecocokan pola antara emisi polusi udara di DKI Jakarta, Surabaya, maupun Semarang dengan hipotesis EKC.

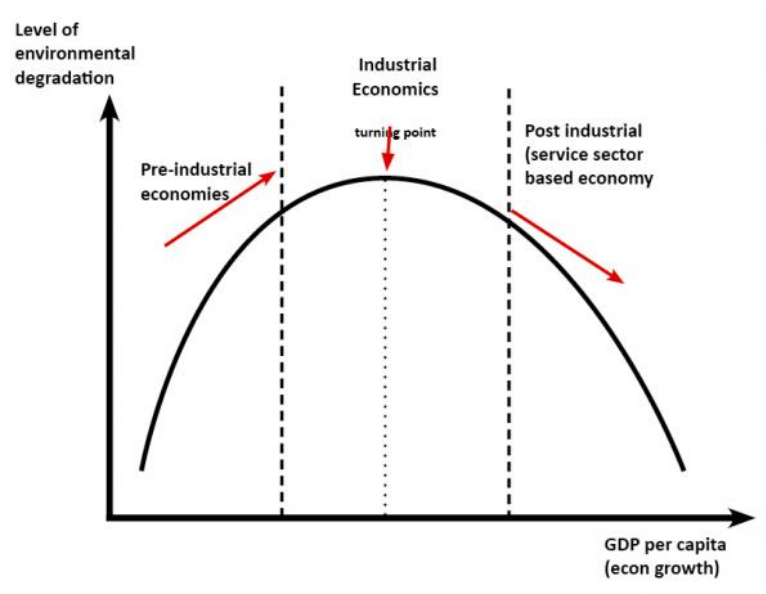

Gambar 1. Environtmental Kuznet Curve (Sumber: https://www.economicshelp.org)

\section{HASIL DAN PEMBAHASAN}

Industrialisasi berawal dari industri kecil dan kemudian bergerak ke industri berat. Pergerakan ini akan meningkatkan penggunaan sumberdaya alam, dan peningkatan degradasi lingkungan. Setelah itu industrialisasi akan memperluas perannya pada pembentukan produk nasional domestik yang semakin stabil. Environmental Kuznets Curve (EKC) dikenal sebagai teori pertama yang menggambarkan bagaimana hubungan antara tingkat pertumbuhan ekonomi dengan degradasi lingkungan sebuah negara. Menurut teori ini ketika pendapatan suatu negara masih tergolong rendah, maka perhatian negara tersebut akan tertuju pada bagaimana cara meningkatkan pendapatan negara, baik melalui produksi, investasi yang mendorong terjadinya 
peningkatan pendapatan dengan mengesampingkan permasalahan kualitas lingkungan. Akibatnya pertumbuhan pendapatan akan diikuti oleh kenaikan tingkat polusi dan kemudian menurun lagi dengan pertumbuhan yang tetap berjalan. Teori ini dikembangkan atas dasar permintaan akan kualitas lingkungan yang meningkatkan pengawasan sosial dan regulasi pemerintah sehingga masyarakat akan lebih sejahtera (Mason dkk., 2003).

Hubungan antara tingkat pertumbuhan ekonomi dengan degradasi lingkungan dapat dilihat dari dua variabel yang mewakili tingkat pertumbuhan ekonomi dan degradasi lingkungan. Variabel mengenai tingkat pertumbuhan ekonomi suatu wilayah dapat dilihat dari peningkatan nilai output dalam bentuk domestik bruto. Hal ini dikarenakan PDRB dalam suatu wilayah dapat menggambarkan keberhasilan kegiatan pembangunan ekonomi pada wilayah tersebut. Sedangkan variabel mengenai degradasi lingkungan kami menggunakan Aerosol Optical Thickness (AOT) yang merupakan nilai representatif dari polusi udara. Kami menggunakan data polusi udara pada AOT karena bersifat temporal. Berdasarkan data yang sudah didapat, selanjutnya kami membuat ratarata AOT setiap tahun. Kami memilih tiga kota besar di Indonesia yang dapat mempresentasikan kota-kota lain di Indonesia yaitu DKI Jakarta, Semarang, dan Surabaya. Ketiga kota tersebut merupakan kota dengan yang memiliki dominasi kegiatan ekonomi yang tinggi dibandingkan dengan kota lainnya. Penelitian kami menggunakan analisis regresi selama 11 tahun yaitu dari tahun 2005 sampai 2015. Pemilihan lama waktu 11 tahun dikarenakan ketersediaan data dan publikasi dari kedua variabel. Selain itu, pada citra MODIS tahun-tahun tersebut memiliki tutupan awan yang relatif sedikit sehingga data AOT dapat diperoleh dengan baik.

\subsection{Hubungan antara polusi udara dan PDRB}

Hubungan antara polusi udara dan PDRB di ketiga kota besar Indonesia menunjukkan hasil yang berbeda. Besaran PDRB di setiap kota rata-rata mengalami kenaikan setiap tahunnya sedangkan besaran AOT di setiap kota mengalami fluktuasi. Berikut tabel besaran AOT dan PDRB DKI Jakarta, Semarang, dan Surabaya Tahun $2005-2015$ :

Tabel 1. Besaran AOT dan PDRB DKI Jakarta, Semarang, dan Surabaya Tahun 2005-2015

Sumber: Dokumentasi penulis

\begin{tabular}{|l|l|l|l|l|l|l|}
\hline \multirow{2}{*}{ Tahun } & \multicolumn{2}{|c|}{ DKI Jakarta } & \multicolumn{2}{c|}{ Semarang } & \multicolumn{2}{c|}{ Surabaya } \\
\cline { 2 - 7 } & AOT & PDRB & AOT & PDRB & AOT & PDRB \\
\hline 2005 & 0,189 & 430999 & 0,156 & 23208 & 0,158 & 96387 \\
\hline 2006 & 0,227 & 494524 & 0,165 & 26624 & 0,133 & 112359 \\
\hline 2007 & 0,169 & 567794 & 0,173 & 30516 & 0,124 & 128198 \\
\hline 2008 & 0,296 & 481354 & 0,159 & 34541 & 0,109 & 162833 \\
\hline 2009 & 0,274 & 755263 & 0,172 & 38465 & 0,110 & 178559 \\
\hline 2010 & 0,233 & 738721 & 0,167 & 43398 & 0,093 & 205161 \\
\hline 2011 & 0,223 & 972923 & 0,251 & 48461 & 0,148 & 235034 \\
\hline 2012 & 0,343 & 1095203 & 0,155 & 54385 & 0,110 & 264336 \\
\hline 2013 & 0,202 & 1363515 & 0,215 & 99756 & 0,088 & 293181 \\
\hline 2014 & 0,207 & 1541003 & 0,242 & 108807 & 0,108 & 327802 \\
\hline 2015 & 0,449 & 1755853 & 0,280 & 122110 & 0,141 & 365351 \\
\hline
\end{tabular}


Berdasarkan tabel 1, diketahui bahwa terdapat hubungan keretaikan atau korelasi antara AOT dan PDRB. Hasil perhitungan dari ketiga kota diperoleh hasil bahwa DKI Jakarta memiliki nilai korelasi sebesar 0.479739438 sedangkan Semarang sebesar 0.281667144 dan Surabaya sebesar 0.810211585 . Nilai tersebut menunjukkan bahwa pada tiap kota memiliki nilai hubungan yang berbeda antara nilai AOT dan PDRB terkait dengan kondisi yang berbeda pada tiap kota. DKI Jakarta dan Semarang memiliki nilai korelasi yang positif menunjukkan bahwa pada tiap kenaikan PDRB dibersamai dengan kenaikan nilai AOT sedangkan Surabaya memiliki nilai korelasi yang negatif yang menunjukkan bahwa pada tiap kenaikan nilai PDRB dibersamai dengan penurunan nilai AOT meskipun hubungan antar kedua variabel pada kota Surabaya cukup rendah.

Tabel 2. Korelasi antara AOT dan PDRB DKI Jakarta, Semarang, dan Surabaya

Sumber: Dokumentasi penulis

\begin{tabular}{lrr}
\hline DKI Jakarta & AOT & PDRB \\
\hline AOT & 1 & \\
PDRB & 0,479739438 & PDRB \\
\hline Semarang & AOT & \\
\hline AOT & 1 & 1 \\
PDRB & 0,810211585 & PDRB \\
\hline Surabaya & AOT & \\
\hline AOT & 1 & 1 \\
PDRB & $-0,281667144$ & \\
\hline
\end{tabular}

Setelah memperoleh hubungan keterkaitan antara AOT dan PDRB DKI Jakarta, Semarang, dan Surabaya. Selanjutnya kami mencari nilai koefisien determinasi dan arah hubungan secara matematis dari setiap kota, di mana AOT sebagai variabel dependen dan PDRB sebagai variabel independen. Penyelidikan nilai hubungan dilakukan dengan beberapa model regresi yaitu exponensial, linier, logaritmik, polynomial orde 2, polynomial orde 3, dan power. Keenam model regresi tersebut menghasilkan nilai hubungan dan persamaan yang berbedabeda pada setiap kota dan ditampilkan dalam kedua tabel berikut (Tabel 3 dan 4);

Tabel 3. Nilai Koefisien Determinasi $\left(\mathrm{R}^{2}\right)$ DKI Jakarta, Semarang, dan Surabaya

Sumber: Dokumentasi penulis

\begin{tabular}{|l|c|c|c|c|c|c|}
\hline \multicolumn{1}{|c|}{ Kota } & Exponensial & Linier & Logaritmik & $\begin{array}{c}\text { Polynomial } \\
\text { Orde 2 }\end{array}$ & $\begin{array}{c}\text { Polynomial } \\
\text { Orde 3 }\end{array}$ & Power \\
\hline Jakarta & 0,165 & 0,187 & 0,193 & 0,302 & 0,522 & 0,187 \\
\hline Semarang & 0,657 & 0,656 & 0,623 & 0,664 & 0,707 & 0,630 \\
\hline Surabaya & 0,080 & 0,079 & 0,148 & 0,413 & 0,414 & 0,147 \\
\hline
\end{tabular}


Tabel 4. Persamaan Hasil Analisis Regresi (y) DKI Jakarta, Semarang, dan Surabaya Sumber: Dokumentasi penulis

\begin{tabular}{|c|c|c|c|c|c|c|}
\hline \multicolumn{1}{|c|}{ Kota } & $\begin{array}{c}\text { Exponensi } \\
\text { al }\end{array}$ & Linier & $\begin{array}{c}\text { Logaritmi } \\
\mathbf{k}\end{array}$ & $\begin{array}{c}\text { Polynomial } \\
\text { Orde 2 }\end{array}$ & $\begin{array}{c}\text { Polynomial } \\
\text { Orde 3 }\end{array}$ & Power \\
\hline Jakarta & $\begin{array}{c}0,1914 \mathrm{e}^{3 \mathrm{E}-} \\
07 \mathrm{x}\end{array}$ & $\begin{array}{c}9 \mathrm{E}-08 \mathrm{x}+ \\
0,1765\end{array}$ & $\begin{array}{c}0,0724 \ln (\mathrm{x}) \\
-0,7315\end{array}$ & $\begin{array}{c}1 \mathrm{E}-13 \mathrm{x}^{2}-2 \mathrm{E}- \\
07 \mathrm{x}+0,2992\end{array}$ & $\begin{array}{c}7 \mathrm{E}-19 \mathrm{x}^{3}-2 \mathrm{E}- \\
12 \mathrm{x}^{2}+2 \mathrm{E}-06 \mathrm{x} \\
-0,3117\end{array}$ & $0,01 \mathrm{x}^{0,2346}$ \\
\hline Semarang & $\begin{array}{c}0,1431 \mathrm{e}^{5 \mathrm{E}-} \\
06 \mathrm{x}\end{array}$ & $\begin{array}{c}1 \mathrm{E}-06 \mathrm{x}+ \\
0,1357\end{array}$ & $\begin{array}{c}0,061 \ln (\mathrm{x}) \\
0,4648\end{array}$ & $\begin{array}{c}5 \mathrm{E}-12 \mathrm{x}^{2}+3 \mathrm{E}- \\
07 \mathrm{x}+0,1555\end{array}$ & $\begin{array}{c}4 \mathrm{E}-16 \mathrm{x}^{3}-8 \mathrm{E}- \\
11 \mathrm{x}^{2}+5 \mathrm{E}-06 \mathrm{x} \\
+0,069\end{array}$ & $\begin{array}{c}0,0077 \mathrm{x}^{0,29} \\
66\end{array}$ \\
\hline Surabaya & $\begin{array}{c}0,1344 \mathrm{e}^{-6 \mathrm{E}-} \\
07 \mathrm{x}\end{array}$ & $\begin{array}{c}-7 \mathrm{E}-08 \mathrm{x} \\
+0,1354\end{array}$ & $\begin{array}{c}-0,019 \ln (\mathrm{x}) \\
+0,3575\end{array}$ & $\begin{array}{c}2 \mathrm{E}-12 \mathrm{x}^{2}-9 \mathrm{E}- \\
07 \mathrm{x}+0,2191\end{array}$ & $\begin{array}{c}-2 \mathrm{E}-18 \mathrm{x}^{3}+3 \mathrm{E}- \\
12 \mathrm{x}^{2}-1 \mathrm{E}-06 \mathrm{x} \\
+0,2333\end{array}$ & $\begin{array}{c}0,8471 \mathrm{x}^{-} \\
0,161\end{array}$ \\
\hline
\end{tabular}

Berdasarkan kedua tabel tersebut dapat diketahui bahwa bentuk hubungan yang terbaik pada ketiga kota besar antara PDRB dan AOT adalah polynomial orde 3 yang mana pada tiap penurunan maupun peningkatan oleh PDRB dibersamai dengan peningkatan maupun penurunan fluktiatif AOT dan dibuktikan dengan nilai koefisien determinasi tertinggi pada ketiga kota besar yaitu DKI Jakarta sebesar 0,522 Semarang sebesar 0,707 dan Surabaya sebesar 0,414. Bentuk hubungan lain seperti exponensial, linier, logaritmik, maupun power memiliki nilai $\mathrm{R}^{2}$ yang bervariatif pada tiap kota sehingga kurang representatif dan tidak dapat digunakan sebagai acuan bentuk hubungan yang baik untuk kedua variabel yang diujikan yaitu PDRB dan AOT.

Gambar 2, 3, dan 4 memperlihatkan sebaran data dan garis prediktif tiap persamaan model regresi yang digunakan di DKI Jakarta, Semarang, dan Surabaya. Berdasarkan gambar 2 diketahui bahwa plot titik PDRB dan AOT pada DKI Jakarta cenderung positif dengan sebaran data yang acak dan menyebabkan persamaan model regresi yang sesuai hanya bentuk polynomial orde 3 .

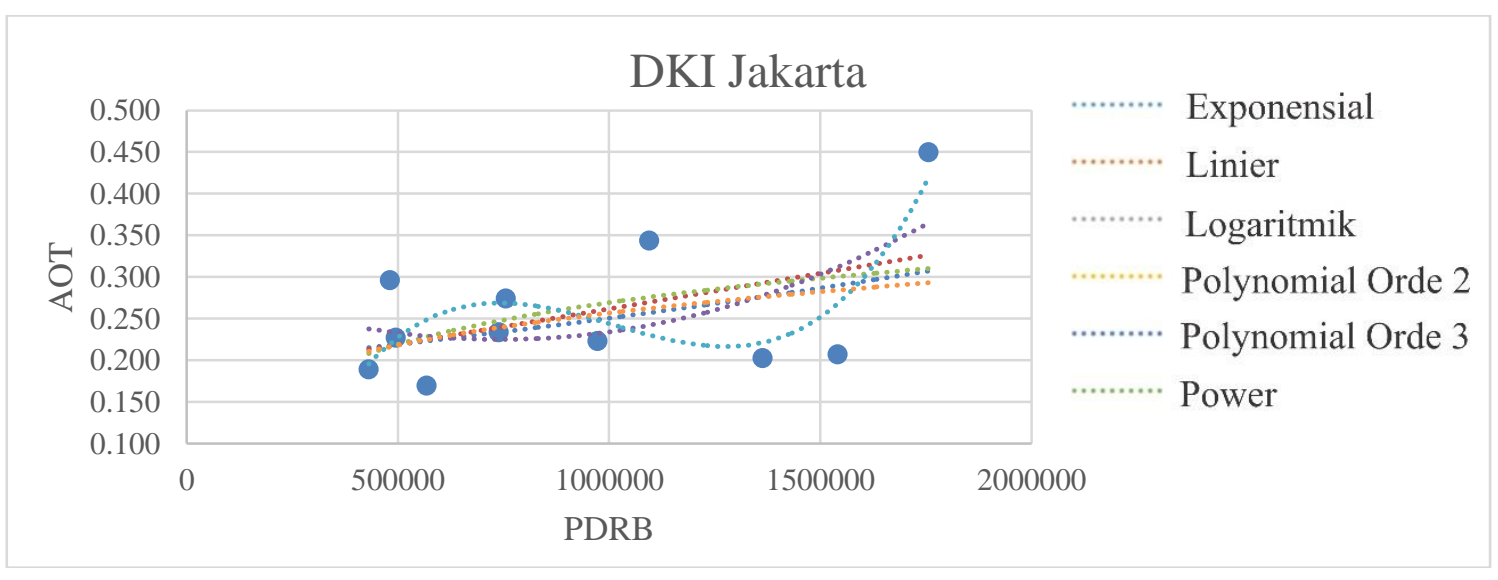

Gambar 2. Grafik Regresi antara AOT dan PDRB DKI Jakarta Sumber: Dokumentasi penulis

Sama halnya dengan DKI Jakarta, Semarang memiliki model persamaan terbaik dengan menggunakan persamaan regresi polynomial orde 3. Namun terdapat perbedaan dibandingkan dengan kondisi sebaran plot
PDRB dan AOT di DKI Jakarta: 1) sebaran PDRB dan AOT lebih mendekati kurva persamaan model, dan 2) rentang nilai PDRB maupun AOT lebih kecil 


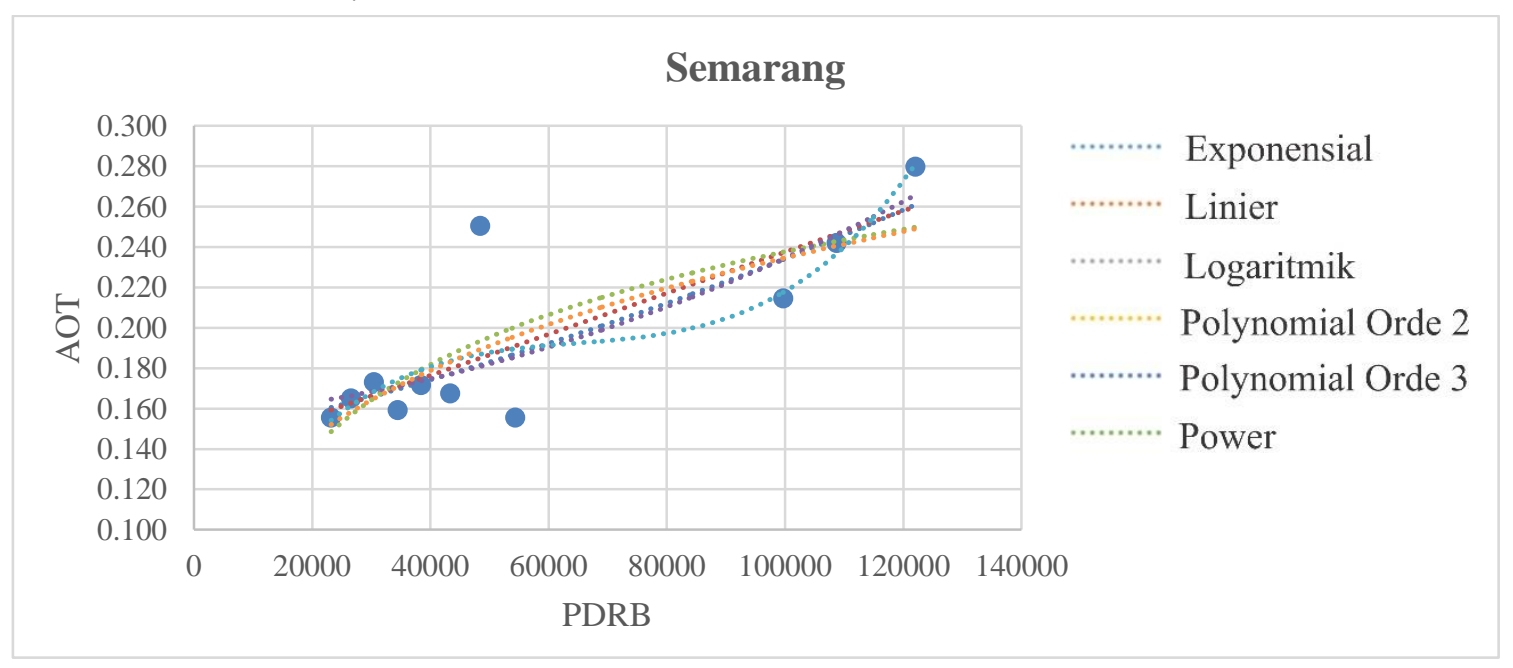

Gambar 3. Grafik Regresi antara AOT dan PDRB Semarang Sumber: Dokumentasi penulis

Kota Surabaya memiliki sifat hubungan AOT dan PDRB yang berbeda dengan DKI Jakarta maupun Semarang karena memiliki nilai korelasi negatif. Gambar 4 memperlihatkan sebaran titik plot yang menyebar secara acak dan hanya dapat dijelaskan dengan model persamaan polynomial orde 2 maupun 3 .

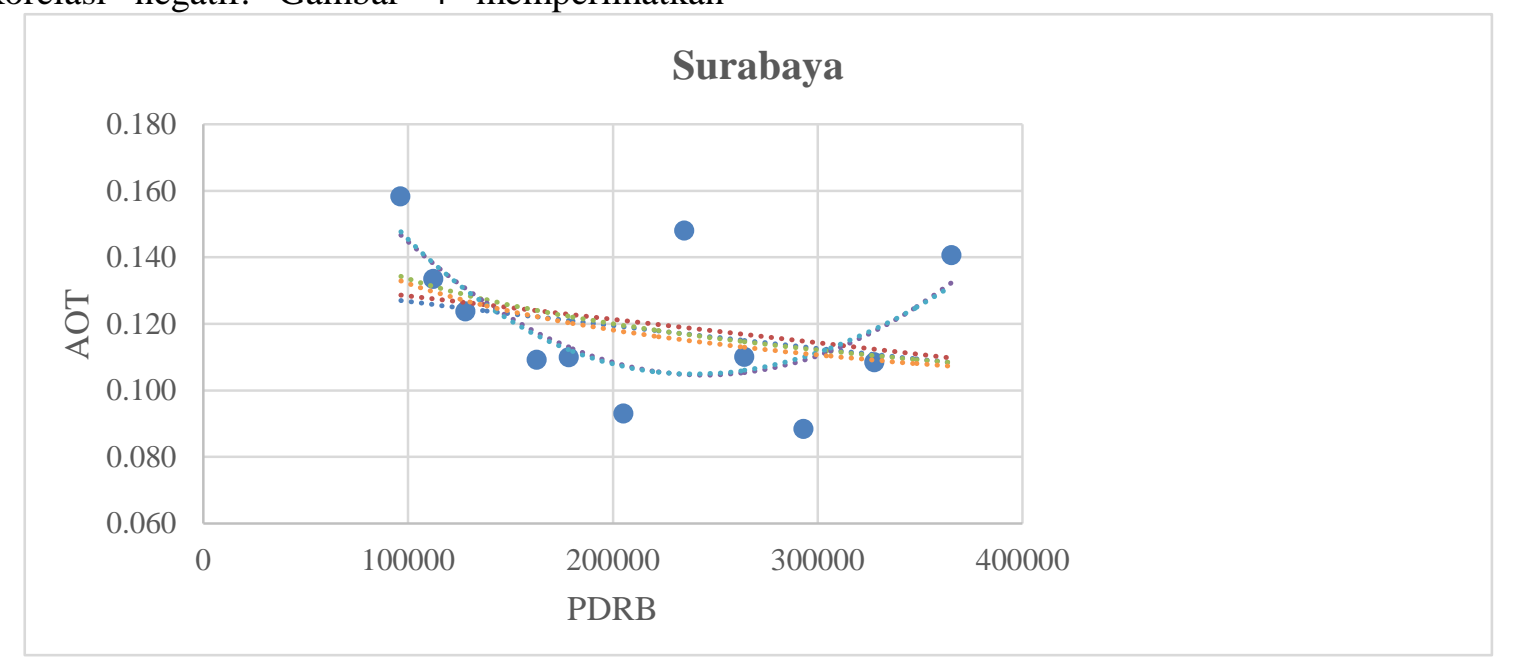

Gambar 4. Grafik Regresi antara AOT dan PDRB Surabaya

Sumber: Dokumentasi penulis

Hasil nilai koefisien determinasi $\left(\mathrm{R}^{2}\right)$ pada ketiga kota (DKI Jakarta, Semarang, dan Surabaya) tidak lebih dari 0,8 yang menandakan bahwa terdapat variabel yang tidak dapat menjelaskan nilai AOT dari variabel PDRB. Sebagai contoh di Kota DKI Jakarta yang memiliki nilai koefisien determinasi $\left(\mathrm{R}^{2}\right)$ 0,522 , sisa dari nilai tersebut adalah 0,478 . Di mana PDRB dapat menjelaskan besarnya AOT sebesar 0,522 atau 52,2\%, sedangkan $47,8 \%$ sisanya dijelaskan oleh variabel-variabel lainnya. Sejatinya polusi yang terjadi tidak hanya dipengaruhi oleh ekonomi. Akan tetapi populasi juga dapat terjadi karena hal lain yang tidak dibahas pada paper ini. Hal ini dapat dikarenakan eror atau kesalahan pada saat proses ekstraksi nilai AOT. Ekstraksi nilai AOT yang kami lakukan adalah dengan mengambil satu citra pada tiap bulan yang kemudian direrata tiap tahunnya untuk memperoleh nilai AOT tahunan, meskipun pada kondisi sebenarnya satu citra tersebut kurang merepresentasikan kondisi rerata AOT pada bulan tersebut. Sehingga eror dapat terjadi pada 
saat di luar tanggal pengambilan data dan menyebabkan hasil yang diperoleh dapat meleset dari kondisi yang sebenarnya.

3.2 Analisis tren untuk rasio konsentrasi AOT dengan PDRB

Kurva hubungan antara AOT dan PDRB menunjukan adanya tren peningkatan pada DKI Jakarta dan Semarang, sementara tren penurunan terjadi pada Surabaya. Hal ini menjadi sebuah indikasi terjadinya proses unik pada tiap kota. Data pengamatan selama sebelas tahun (2005-2015) menunjukan bahwa tren polusi udara DKI Jakarta dan Semarang mengalami peningkatan gradual seiring dengan pertambahan PDRB dengan puncak di tahun 2015. Sementara itu, Surabaya justru mengalami puncak emisi pada 2005 dan semakin berkurang seiring dengan bertambahnya PDRB. Pemahaman mengenai tren polusi udara di DKI Jakarta, Semarang, dan
Surabaya secara lebih mendalam dilakukan dengan pencocokan model Environtmental Kuznet Curve (EKC). Namun, pencocokan dalam data yang dikumpulkan penulis memiliki keterbatasan dalam hal jumlah sampel sehingga menyebabkan penilaian tren masih sangat general dimana tren positif DKI Jakarta dan Semarang belum tentu menjadi indikasi pertumbuhan ekonomi pra-industri, juga tren negatif Surabaya belum tentu menjadi indikasi pertumbuhan ekonomi pasca-industri. Hal ini dilandasi oleh adanya kemungkinan perkembangan industri pada tahap titik balik (puncak indsutri) yang menjadi transisi antara keduanya. Agar mendapatkan pemahaman yang lebih baik, kami mencoba menganalisis tren ini berdasarkan dua pendekatan yakni struktur ekonomi kota dan dinamika penggunaan lahan kota.

\subsubsection{DKI Jakarta}

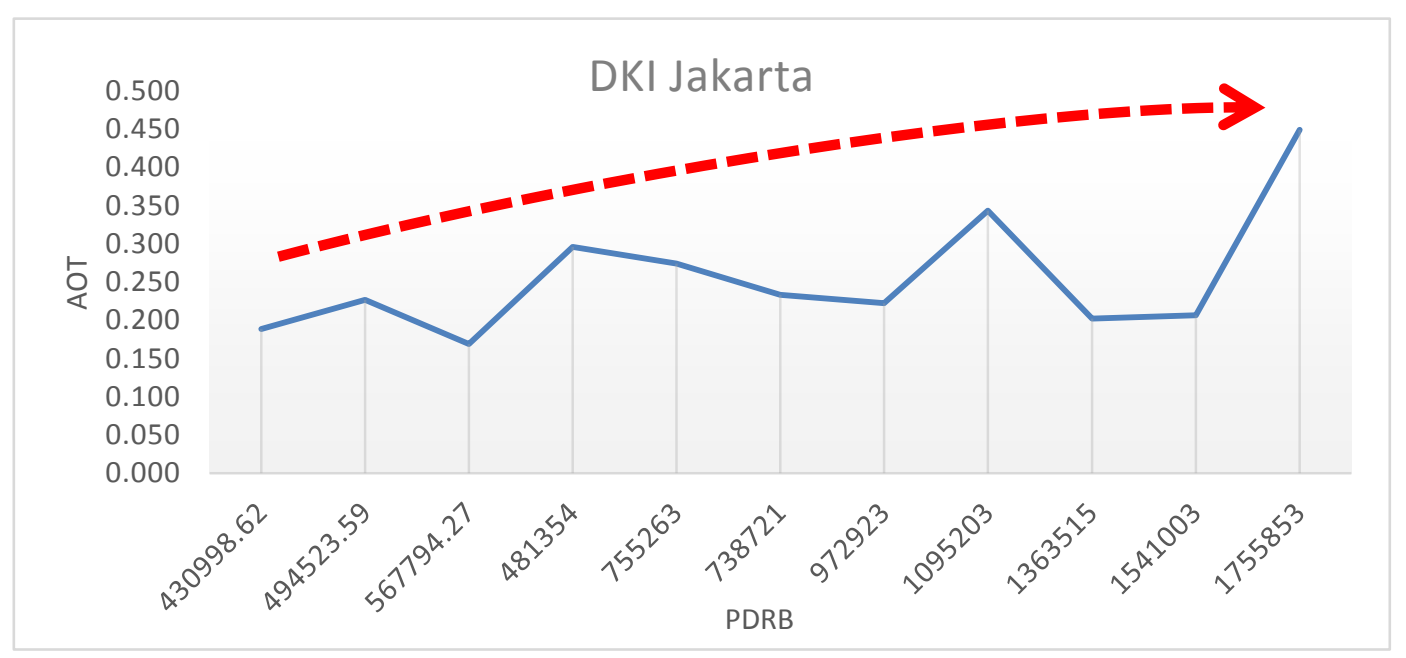

Gambar 5. Grafik Trend AOT DKI Jakarta Dibandingkan dengan PDRB Tahun 2005-2015 Sumber: Dokumentasi penulis 
Secara umum, DKI Jakarta memiliki pertumbuhan ekonomi yang pesat dibandingkan dengan dua kota lainnya yang dikaji dalam paper ini. DKI Jakarta sebagai ibukota pemerintahan sekaligus ibukota ekonomi memegang peranan penting dalam kelangsungan negara. Posisinya yang dianggap strategis menarik lebih banyak penduduk untuk mencari penghidupan sehingga menyediakan banyak sumberdaya manusia untuk dialokasikan ke sektor industri. Hal ini ditandai dengan jumlah tenaga kerja hingga 304.397 orang pada 1451 perusahaan yang berbeda.

Akan tetapi, struktur ekonomi DKI Jakarta (tabel 5) menunjukan adanya sektor lain yang lebih signifikan kontribusinya dalam PDRB yakni pada sektor keuangan, real estate, dan jasa perusahaan serta perdagangan, hotel, dan restoran. Pergerakan roda ekonomi DKI Jakarta tidak hanya terpaku pada sektor sekunder, justru sektor tersier memberikan kontribusi yang lebih banyak (hingga 46\%) terhadap PDRB DKI Jakarta secara keseluruhan.

Tabel 5. Struktur Ekonomi DKI Jakarta (nilai dalam persen)

Sumber: BPS

\begin{tabular}{|l|r|r|r|r|r|r|r|r|r|r|r|r|}
\hline Lapangan Usaha & 2005 & 2006 & 2007 & 2008 & 2009 & 2010 & 2011 & 2012 & 2013 & 2014 & 2015 & Rerata \\
\hline Pertanian & 0.12 & 0.12 & 0.12 & 0.12 & 0.12 & 0.12 & 0.11 & 0.11 & 0.11 & 0.1 & 0.09 & 0.11 \\
\hline Pertambangan dan Penggalian & 0.27 & 0.3 & 0.29 & 0.3 & 0.24 & 0.25 & 0.32 & 0.29 & 0.28 & 0.26 & 0.25 & 0.28 \\
\hline Industri Pengolahan & 14.15 & 14.12 & 14.15 & 13.91 & 13.78 & 13.91 & 13.82 & 13.79 & 13.54 & 13.59 & 13.84 & 13.87 \\
\hline Listrik, Gas, dan Air Bersih & 0.6 & 0.55 & 0.55 & 0.61 & 0.58 & 0.52 & 0.47 & 0.42 & 0.37 & 0.36 & 0.34 & 0.49 \\
\hline Konstruksi & 12.86 & 13.53 & 13.56 & 13.65 & 13.8 & 13.78 & 13.76 & 13.8 & 13.63 & 13.36 & 13.16 & 13.54 \\
\hline Perdangan, Hotel, dan Restoran & 21 & 20.83 & 21.15 & 21.47 & 21.39 & 21.48 & 21.6 & 21.45 & 22.03 & 22.55 & 22 & 21.54 \\
\hline Pengangkutan dan Komunikasi & 8.07 & 8.7 & 9.21 & 9.24 & 9.78 & 10.06 & 10.18 & 10.24 & 10.34 & 10.41 & 10.43 & 9.70 \\
\hline Keuangan, Real Estate, dan Jasa perusahaan & 26.88 & 25.98 & 24.82 & 24.73 & 24.34 & 23.92 & 23.82 & 23.86 & 23.77 & 23.41 & 23.68 & 24.47 \\
\hline Jasa-jasa & 16.05 & 15.87 & 16.15 & 15.97 & 15.97 & 15.96 & 15.92 & 16.04 & 15.93 & 15.96 & 16.21 & 16.00 \\
\hline Jumlah & 100 & 100 & 100 & 100 & 100 & 100 & 100 & 100 & 100 & 100 & 100 & \\
\hline
\end{tabular}

Lapangan usaha yang termasuk dalam kelas sektor tersier menjadi sebuah petunjuk bahwa bentuk tren polusi DKI Jakarta yang agak bias. Lapangan usaha perdagangan dan jasa mengemisikan polutan udara yang jauh lebih sedikit daripada industri karena tidak berkaitan langsung dengan proses pelepasan gas maupun polutan ke udara (Tomasi dkk. 2016). Sementara nilai PDRB yang dihasilkan oleh sektor tersebut justru semakin meningkat sehingga bentuk garis tren menjadi tidak sepenuhnya linier. Meski demikian, kecenderungan peningkatan AOT seiring dengan pertambahan PDRB masih terus ada. Selain nilai polusi dan ekonomi yang terus meningkat, kawasan industri di DKI Jakarta juga terus mengalami ekspansi secara spasial. Peta kawasan industri hasil interpretasi visual menunjukan adanya perubahan luasan kawasan industri yang cukup signifikan dari tahun 2005 hingga tahun 2015 (Gambar 6). Hal ini menunjukan masih adanya fokus kegiatan industri di DKI Jakarta setidaknya hingga tahun 2015. Apabila garis tren dikelaskan berdasarkan EKC, DKI Jakarta kemungkinan besar tengah berada dalam kota industri menuju titik balik ditandai dengan menurunnya polusi udara di beberapa tahun. 


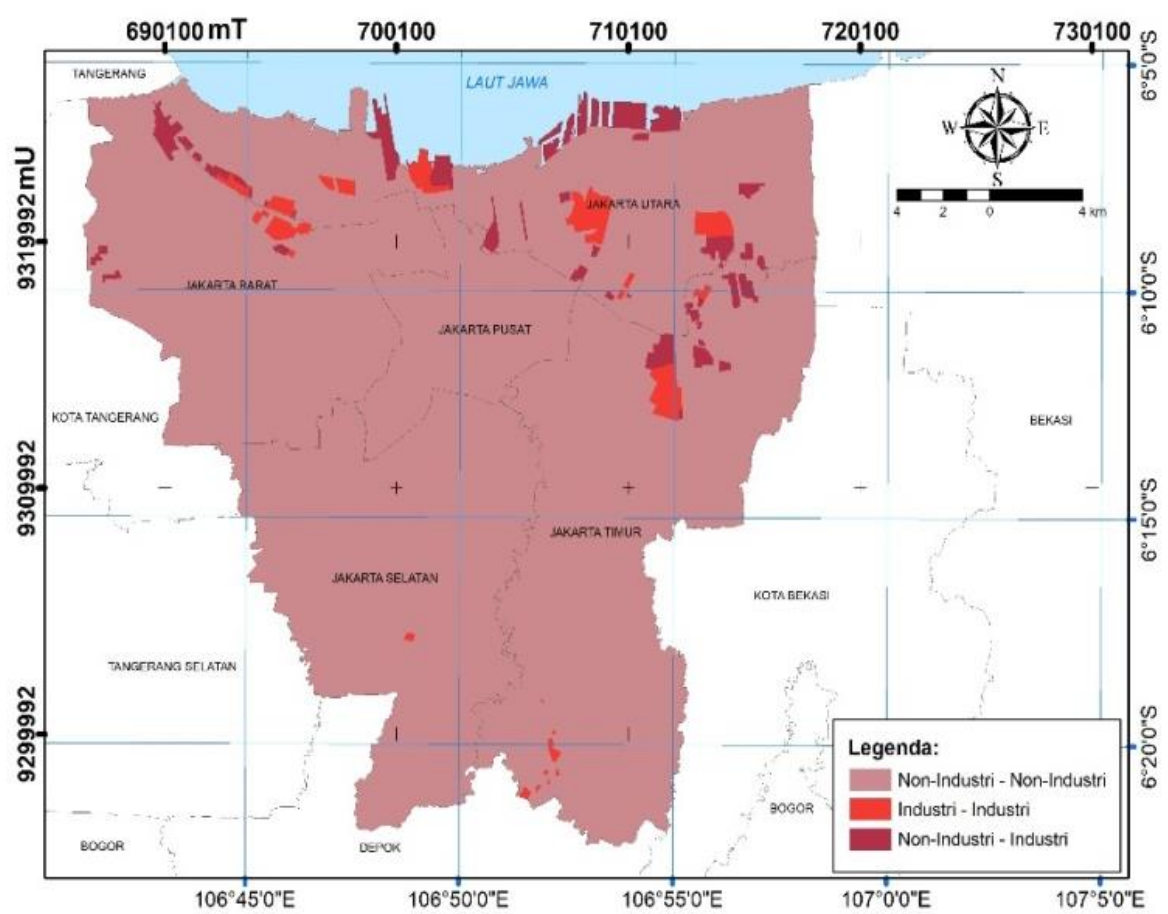

Gambar 6. Peta Perubahan Luasan Kawasan Industri DKI Jakarta Tahun 2005-2015 Sumber: Dokumentasi penulis

\subsubsection{Semarang}

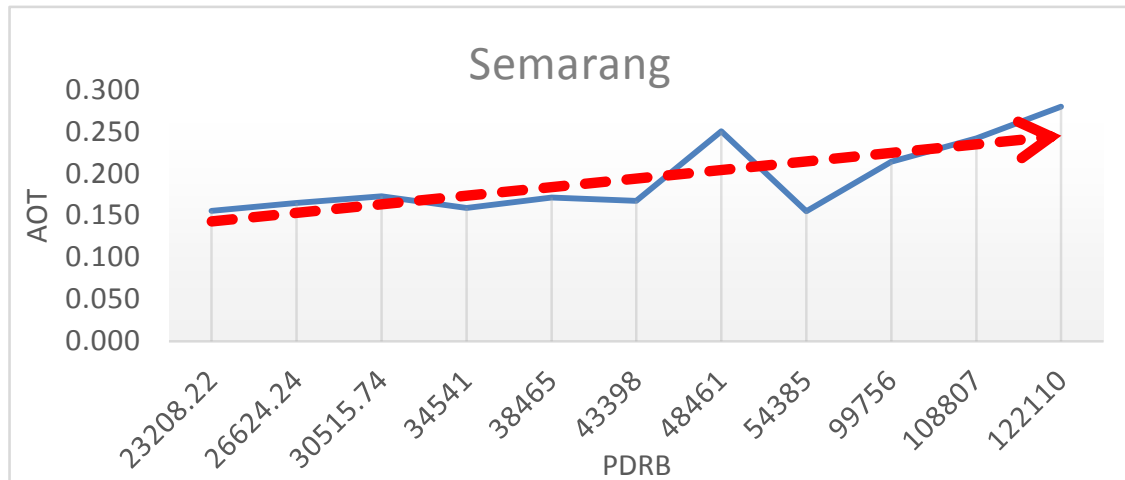

Gambar 7. Grafik Trend AOT Semarang Dibandingkan dengan PDRB Tahun 2005-2015 Sumber: Dokumentasi penulis

Perkembangan Kota Semarang pada awalnya dimulai dari abad ke-8 Masehi yang dahulu dikenal denang nama Pragota. Semarang berkembang pesat semenjak kedatangan armada laksamana Cheng Ho di pelabuhan simongan pada tahun 1405 yang kemudian dilanjutkan dengan pembangunan perumahan maupun villa oleh pemerintah belanda pada tahun 1705 dan terus berkembang bahkan setelah masa kemerdekaan hingga menjadi salah satu kota metropolitan yang penting di level nasional (Purwanto, 2005). Sektor industri memegang peranan yang penting dalam perekonomian Semarang. Hal ini ditunjukan dengan kontribusi industri dalam PDRB yang cukup dominan dibadningkan dengan sektor-sektor lain (Tabel 6). Meski tidak se-masif DKI Jakarta, Semarang juga memiliki kawasan industri yang cukup aktif terkonsentrasi pada segitiga Simpang Lima City Center, Pemuda Central Business District, dan Gadjah Mada Golden Triangle dengan jumlah pekerja mencapai 91.829 yang dipekerjakan dalam 377 industri besar dan sedang yang berbeda (BPS, 2009). 
Tabel 6. Struktur Ekonomi Semarang (nilai dalam persen)

Sumber: BPS

\begin{tabular}{|l|c|r|r|r|r|r|r|r|r|r|r|r|}
\hline Lapangan Usaha & $\mathbf{2 0 0 5}$ & $\mathbf{2 0 0 6}$ & $\mathbf{2 0 0 7}$ & $\mathbf{2 0 0 8}$ & $\mathbf{2 0 0 9}$ & $\mathbf{2 0 1 0}$ & $\mathbf{2 0 1 1}$ & $\mathbf{2 0 1 2}$ & $\mathbf{2 0 1 3}$ & $\mathbf{2 0 1 4}$ & $\mathbf{2 0 1 5}$ & Rerata \\
\hline Pertanian, Peternakan, Kehutanan dan Perikanan & - & 1.21 & 1.2 & 1.15 & 1.15 & 1.17 & 1.15 & 1.08 & 1.08 & 1.01 & 1.01 & 1.121 \\
\hline Pertambangan dan Penggalian & - & 0.2 & 0.19 & 0.18 & 0.17 & 0.17 & 0.16 & 0.15 & 0.15 & 0.19 & 0.2 & 0.176 \\
\hline Industri Pengolahan & - & 26.85 & 25.83 & 25.13 & 24.66 & 24.16 & 24.36 & 24.63 & 24.63 & 27.61 & 27.55 & 25.541 \\
\hline Listrik, Gas dan Air Bersih & - & 1.83 & 1.74 & 1.66 & 1.58 & 1.53 & 1.47 & 1.43 & 1.43 & 0.19 & 0.18 & 1.304 \\
\hline Bangunan & - & 16.7 & 17.74 & 18.52 & 19.38 & 19.82 & 19.68 & 19.42 & 19.42 & 26.88 & 27.02 & 20.458 \\
\hline Perdagangan, Hotel dan Restoran & - & 28.1 & 28.31 & 28.87 & 28.31 & 27.92 & 28.01 & 28.43 & 28.43 & 17.7 & 17.53 & 26.161 \\
\hline Pengangkutan dan Komunikasi & - & 10.37 & 10.07 & 9.77 & 9.92 & 9.82 & 9.55 & 9.36 & 9.36 & 10.81 & 10.79 & 9.982 \\
\hline Keuangan, Persewaan dan Jasa Perusahaan & - & 2.9 & 2.91 & 2.88 & 2.8 & 2.73 & 2.68 & 2.67 & 2.67 & 7.64 & 7.8 & 3.768 \\
\hline Jasa- Jasa & - & 11.85 & 12.01 & 11.84 & 12.03 & 12.69 & 12.94 & 12.83 & 12.83 & 7.97 & 7.92 & 11.491 \\
\hline Jumlah & no data & 100 & 100 & 100 & 100 & 100 & 100 & 100 & 100 & 100 & 100 & \\
\hline
\end{tabular}

Selain struktur ekonomi, identifikasi tren polusi Semarang juga dilihat berdasarkan dinamika penggunaan lahannya. Kawasan industri pada Kota Semarang yang terkonsentrasi pada tiga kawasan terpadu mengalami ekspansi yang cukup signifikan seluas 504.124 ha atau sekitar 1.6 kali lipat dari luas sebelumnya (Gambar 8). Hal ini turut menjadi indikator bahwa Semarang mengalami pemusatan ekonomi secara intensif pada sektor industri. Mengkombinasikan fakta tersebut, Semarang dapat secara tegas dikatakan berada pada tahap pre-industrial economics menurut pencocokan tren dengan EKC. Tahap ini mendefinisikan Semarang sebagai kota dengan fokus pada peningkatan nilai produksi dari segala sumberdaya dan belum mengimplementasikan regulasi penekanan polusi udara secara menyeluruh.

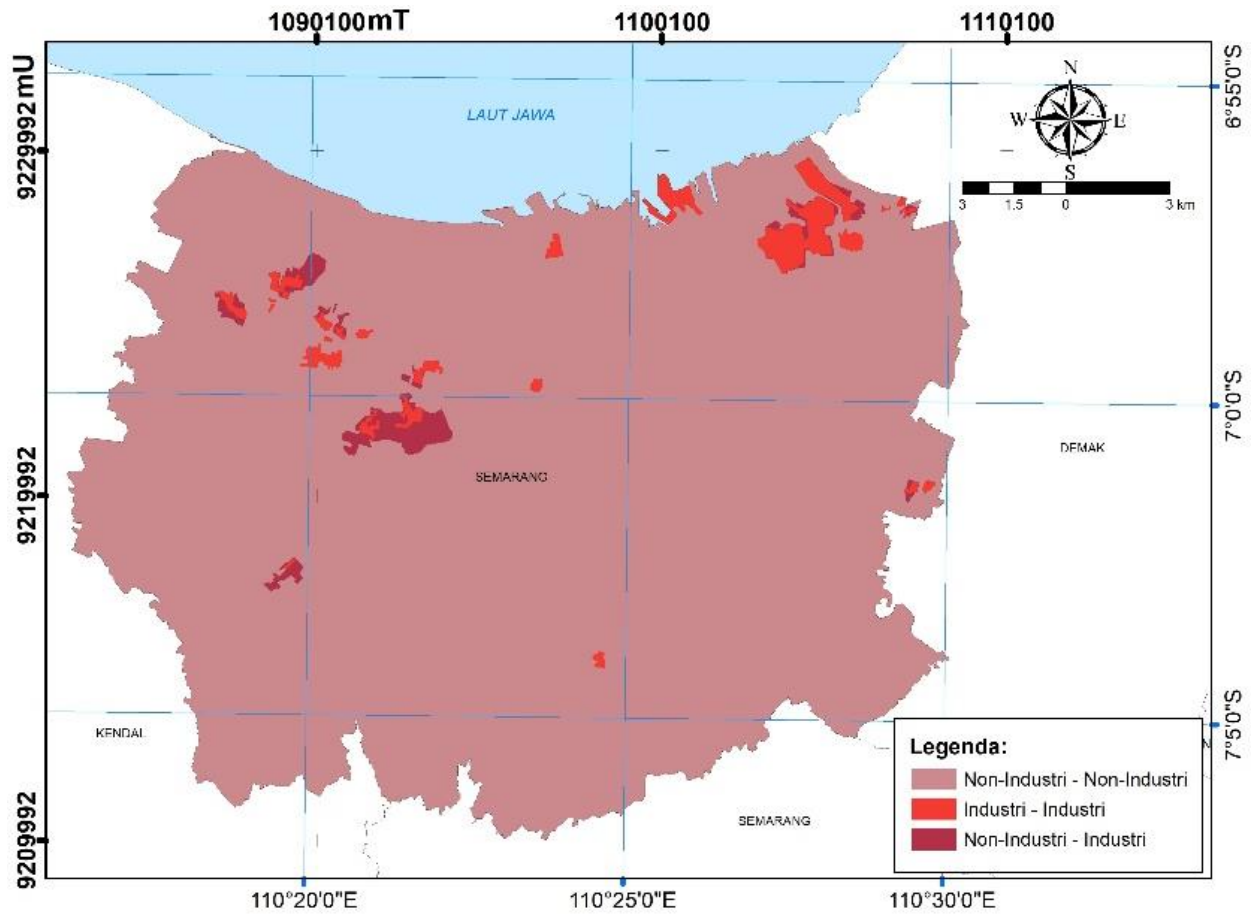

Gambar 8. Peta Perubahan Luasan Kawasan Industri Semarang Tahun 2005-2015 Sumber: Dokumentasi penulis 


\subsubsection{Surabaya}

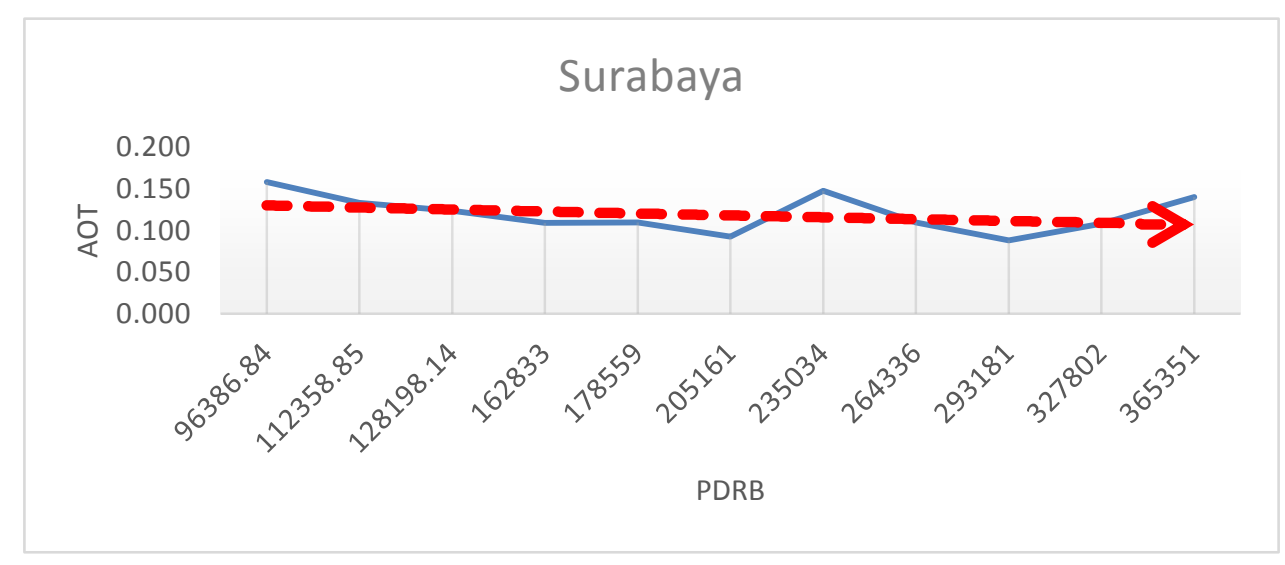

Gambar 9. Grafik Trend AOT Surabaya Dibandingkan dengan PDRB Tahun 2005-2015 Sumber: Dokumentasi penulis

Sejak 1990-an, Surabaya telah menjadi salah satu kota pelabuhan perdagangan yang paling penting di Asia. Berbagai komoditas masuk dan keluar melalui Surabaya untuk mengcover Jawa, Kalimantan, dan Indonesia bagian timur. Perkembangannya di bidang perdagangan tersebut memicu pertumbuhan infrastruktur finansial seperti bank, asuransi, dan perusahaan ekspor-impor. Hal ini berimplikasi pada dominasi sektor perdagangan dan jasa dalam kontribusinya terhadap PDRB Surabaya (Tabel 7). Sementara itu, berbagai sektor industri pengelolaan dan manufaktur diletakan pada area luar Surabaya seperti Gresik dan Pasuruan. Hal ini diindikasi menjadi penyebab tren penurunan hubungan AOT dan PDRB dari tahun ke tahun di Surabaya.

Tabel 7. Struktur Ekonomi Surabaya (nilai dalam persen)

\begin{tabular}{|c|c|c|c|c|c|c|c|c|c|c|c|c|}
\hline \multicolumn{13}{|c|}{ Sumber: BPS } \\
\hline Lapangan Usaha & 2005 & 2006 & 2007 & 2008 & 2009 & 2010 & 2011 & 2012 & 2013 & 2014 & 2015 & Rerata \\
\hline Pertanian, Peternakan, Kehutanan dan Perikanan & - & - & - & 0.21 & 0.20 & 0.20 & 0.19 & 0.18 & 0.19 & 0.18 & 0.18 & 0.1915 \\
\hline Pertambangan dan Penggalian & - & - & - & 0.01 & 0.01 & 0.01 & 0.01 & 0.01 & 0.01 & 0.01 & 0.01 & 0.0096 \\
\hline Industri Pengolahan & - & - & - & 27.19 & 20.91 & 19.97 & 19.57 & 19.5 & 19 & 19.42 & 19.23 & 20.599 \\
\hline Listrik, Gas dan Air Bersih & - & - & - & 1.87 & 1.70 & 1.54 & 1.24 & 1.02 & 0.77 & 0.71 & 0.67 & 1.1895 \\
\hline Bangunan & - & - & - & 9.76 & 10.19 & 10.25 & 10.23 & 10.2 & 10.26 & 10.37 & 10 & 10.157 \\
\hline Perdagangan, Hotel dan Restoran & - & - & - & 36.97 & 40.65 & 41.20 & 41.79 & 42.35 & 42.45 & 42.16 & 42.66 & 41.279 \\
\hline \begin{tabular}{|l|} 
Pengangkutan dan Komunikasi \\
\end{tabular} & - & - & - & 8.79 & 10.02 & 10.30 & 10.53 & 10.61 & 10.77 & 10.71 & 10.72 & 10.306 \\
\hline Keuangan, Persewaan dan Jasa Perusahaan & - & - & - & 9.70 & 9.87 & 9.82 & 9.81 & 9.85 & 10.28 & 10.28 & 10.4 & 10.001 \\
\hline Jasa- Jasa & - & - & - & 5.51 & 6.45 & 6.71 & 6.63 & 6.29 & 6.29 & 6.16 & 6.14 & 6.272 \\
\hline Jumlah & no data & no data & no data & 100 & 100 & 100 & 100 & 100 & 100 & 100 & 100 & \\
\hline
\end{tabular}

Meski demikian, sektor industri di Surabaya masih memegang dominasi yang tinggi setelah perdagangan dengan nilai yang signifikan. Hal ini ditandai dengan ekspansi kawasan industri secara spasial dari tahun 2005-2015 seluas 336.727 ha (Gambar 10). Berbeda dengan DKI Jakarta dan Semarang, peningkatan aset dari sektor industri justru cenderung berbanding terbalik dengan besarnya polusi udara. Hal ini diindikasi muncul sebagai bentuk Surabaya yang dalam EKC tengah memasuki tahap post-industrial. Tahap ini mendeskripsikan suatu daerah yang tidak hanya berfokus pada peningkatan nilai produksi, tetapi juga memulai regulasi dalam manajemen lingkungan. 


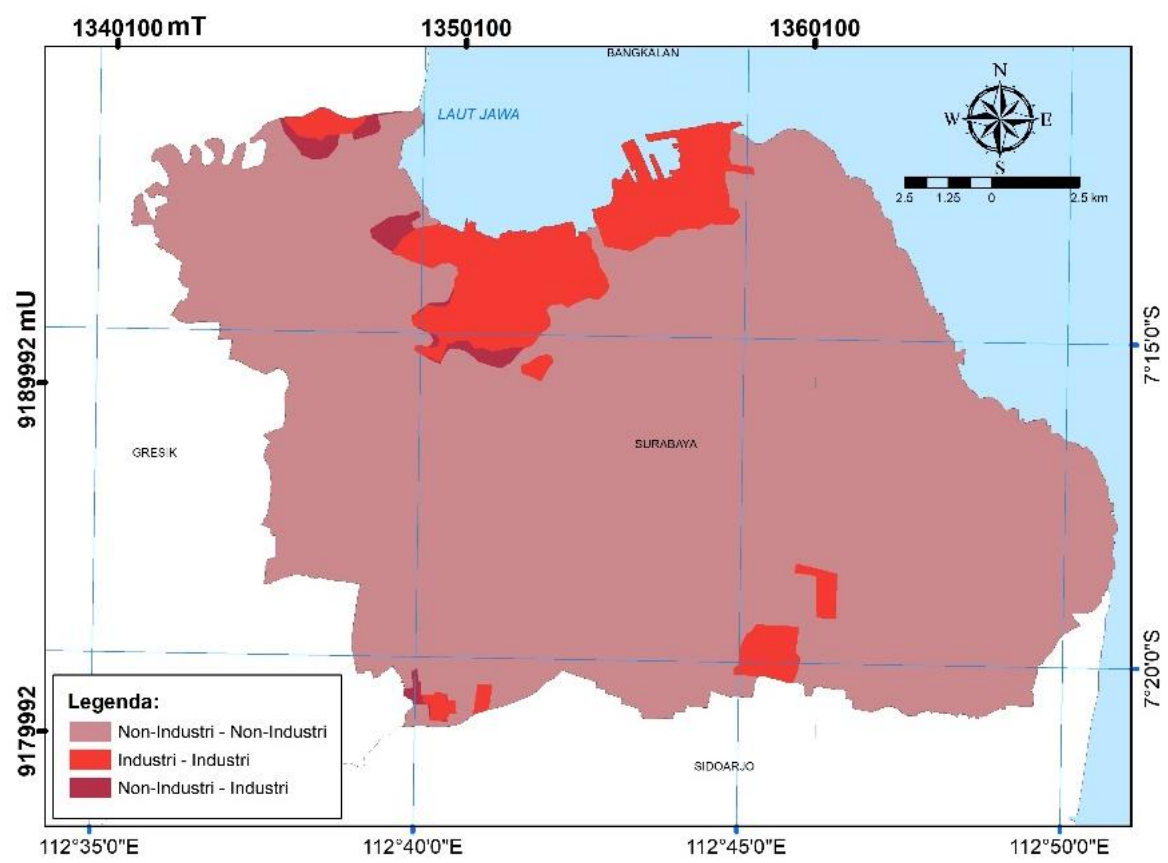

Gambar 10. Peta Perubahan Luasan Kawasan Industri Surabaya Tahun 2005-2015 Sumber: Dokumentasi penulis

\section{DISKUSI}

Environtmental Kuznet Curve (EKC) merupakan turunan dari konsep Kuznet Curve. Kuznet curve merupakan sebuah hopotesis yang merepresentasikan tahap kesenjangan ekonomi pada level ekonomi tertentu dengan bentuk $\mathrm{U}$ terbalik. Konsep ini kemudian berkembang ke arah hipotesis mengenai pola kecenderungan emisi seiring dengan pertumbuhan ekonomi. Meski cukup kokoh, hipotesis ini menuai banyak kritik secara konseptual (Ansuategi dkk. 1998; Arrow dkk., 1995; Ekins, 1997; Pearson, 1994). Grafik EKC yang sifatnya parsial memberikan kesulitan interpretasi pada data yang minim. Bisa jadi, rentang waktu yang dikaji tidak merepresentasikan perkembangan industri secara menyeluruh pada suatu kota. Oleh karenanya, grafik tidak terlihat membentuk U terbalik, melainkan hanya tren menurun atau memuncak saja, Grafik EKC juga memiliki penyimpangan lain dimana tren yang tergambar pada wilayah kajian di beberapa penelitian lain (Stern dkk. 1996) memang cocok, tetapi dengan beberapa tanda yang dianggap error. Selain itu, penilaian pola EKC di beberapa negara memunculkan bentuk tren yang sangat spesifik dan tidak bisa digeneralkan sebagai standar EKC di seluruh dunia

Poin lain mengenai kritik EKC antara lain 1) tidak adanya pengaruh kerusakan lingkungan terhadap pertumbuhan ekonomi secara jelas; 2) keberadaan hubungan EKC kemungkinan besar terjadi karena adanya transaksi pada industri yang berpolusi; 3) adanya kecenderungan negara maju dengan PDRB besar yang dapat mengurangi emisi lebih mudah daripada negara berkembang karena alasan politis; 5) manajemen lingkungan pada ranah hukum legal yang justru lebih berpengaruh pada polusi daripada ekonomi.

DKI Jakarta misalnya, memiliki pola khusus yang terjadi terkait dengan intensitas polusi udara. Grafik tren yang menunjukan adanya gejala penurunan tren pencemaran yang terjadi antara lain pada tahun 2007, 2011, 2013, dan 2014. Terdapat beberapa indikasi yang diduga mempengaruhi penurunan tren tersebut diantaranya adalah berlakunya 
beberapa undang-undang lingkungan hidup berikut:

1. Peraturan MENLH Nomor 05 Tahun 2006 tentang Ambang Batas Emisi Gas Buang Kendaraan Bermotor Lama

2. Peraturan MENLH Nomor 07 Tahun 2007 tentang Baku Mutu Emisi Sumber Tidak Bergerak Bagi Ketel Uap

3. Peraturan MENLH Nomor 17 Tahun 2008 tentang Baku Mutu Emisi Sumber Tidak Bergerak Bagi Usaha dan/atau Kegiatan Industri Keramik

4. Peraturan MENLH Nomor 18 Tahun 2008 Baku Mutu Emisi Sumber Tidak Bergerak Bagi Usaha dan/atau Kegiatan Industri Carbon Black

5. Peraturan MENLH Nomor 04 Tahun 2009 tentang Ambang Batas Emisi Gas Buang Kendaraan Bermotor Tipe Baru

6. Peraturan MENLH Nomor 12 Tahun 2010 tentang Pelaksanaan Pengendalian Pencemaran Udara di Daerah

7. Peraturan MENLH Nomor 35 Tahun 2009 tentang Pengelolaan Halon

8. Peraturan MENLH Nomor 04 Tahun 2011 tentang Standar Kompetensi dan Sertifikasi Kompetensi Penanggung Jawab Pengendalian Pencemaran Udara

9. Peraturan MENLH Nomor 07 Tahun 2012 tentang Pengelolaan Emisi Sumber Tidak Bergerak Bagi Usaha dan/atau Kegiatan Industri Rayon

10. Peraturan MENLH Nomor 10 Tahun 2012 tentang Baku Mutu Emisi Gas Buang Kendaraan Bermotor Tipe Baru Kategori L3

11. Peraturan MENLH Nomor 23 Tahun 2012 tentang Perubahan Atas Peraturan MENLH Nomor 10 Tahun 2012 tentang Baku Mutu Emisi Gas Buang Kendaraan Bermotor Tipe Baru Kategori L3

Secara spesifik, DKI Jakarta telah mengeluarkan Peraturan Daerah No.2 Tahun 2005 tentang Pengendalian Pencemaran Udara yang mulai diimplementasikan di tahun-tahun berikutnya. Implementasi berbagai peraturan resmi tersebut menunjukan DKI Jakarta yang progresif ke arah manajemen lingkungan yang cukup baik. Hal ini menunjukan bahwa tidak hanya aspek teknis, melainkan juga berbagai aspek lain seperti hukum, edukasi masyarakat, dan dan kesiapan institusi turut serta berpengaruh dalam terwujudnya industri yang berkelanjutan.

Industrialisasi Kota Semarang merujuk data yang dilansir dari data Disperindag Kota Semarang menyebutkan jumlah total industri kecil, sedang dan besar di Kota Semarang pada 2013 sebanyak 3.325. Dari jumlah tersebut, sekitar 2.000-an berkategori industri sedang dan besar dengan nilai investasi di atas Rp200 juta. Berkembangnya kawasan industri di Semarang yang semakin dominan dapat mengakibatkan permasalahan terhadap pengelolaan lingkungan. Jumlah industri kecil, sedang dan besar di Kota Semarang yang signifikan tersebut telah memberikan sebuah indikator adanya kemajuan dalam praktik industrialisasi di Kota Semarang yang sembilan kawasan industri (Perman dan Stern, 2003). Ke sembilan kawasan Industri tersebut adalah:

1. Kawasan industri Wijayakusuma;

2. Kawasan Industri Terboyo;

3. Kawasan Industri Lamicitra Nusantara;

4. Kawasan Industri Bukit Semarang Baru;

5. Lingkungan industri Kecil Bugangan Baru;

6. Kawasan Industri Guna Mekar Tambak Aji;

7. Kawasan Industri Candi;

8. Kawasan Industri Tugu, dan

9. Kawasan Industri Sinar Centra Cipta.

Pemaksimalan pengembangan kawasan industri akan berdampak pada peningkatan jumlah pendapatan asli daerah yang memiliki pandangan pada pendapatan. Pemerintah daerah dihadapkan pada aturan-aturan, salah satunya adalah Peraturan Daerah Pemerintah Kota Semarang No. 14 Tahun 2011 tentang Rencana Tata dan Ruang Wilayah. Ketidak 
sesuain pemerapan penegak hukum dalam pengelolaan industrialisasi, dapat berakibat buruk pada penggelolaan lingkungan. Pengelolaan lingkungan yang tidak baik dapat meliputi limbah, mulai dari limbah cair hingga limbah gas seperti polusi udara.

Peraturan Daerah Pemerintah Kota Semarang No. 14 Tahun 2011 tentang Rencana Tata dan Ruang Wilayah mengacu pada penjelasan Peraturan Pemerintah No. 24 Tahun 2009 tentang Kawasan Industri yang menyatakan bahwa; Pembangunan industri merupakan salah satu pilar pembangunan perekonomian nasional yang diarahkan dengan menerapkan pinsip-prinsip pembangunan industri yang berkelanjutan yang didasarkan pada aspek pembangunan ekonomi, sosial dan lingkungan hidup. Aspek lingkungan hidup dalam pengembangan kawasan industri akan mendukung peningkatan kualitas lingkungan hidup di daerah sekitarnya.

Aspek lingkungan memiliki peran yang penting dalam kelangsungan hidup manusia. Di mana dalam pengembangan kawasan industri di suatu daerah harus memperhatikan masalah limbah. Selain itu, juga akan berdampak pada manusia. Semakin berkembang kawasan industri suatu daerah, tingkat polusi udara akan meningkat bersamaan dengan peningkatan fasiltas industri yang mengakibatkan peningkatan pendapatan daerah tersebut. dibutuhkan tata kelola yang baik untuk tercapainya kawasan industri yang baik pula Di Kota Semarang, pemerintah daerah telah menerbitkan Peraturan Daerah Pemerintah Kota Semarang No 14 tahun 2011 tentang Rencana Tata dan Ruang Wilayah, yang isinya mengatur lokasi yang dijadikan sebagai kawasan industri. Regulasi yang dibuat tersebut telah berpijak pada Peraturan Pemerintah No 24 Tahun 2009 tentang Kawasan Industri.

Sama halnya dengan Semarang dan DKI Jakarta, Surabaya memiliki beberapa peraturan daerah yang menyebabkan perubahan tren pada rerata nilai AOT tahunan. Beberapa tahun yang menjadi titik perubahan tren diantaranya adalah tahun 2010, 2011, dan 2013. Pada tahun 2005 hinga 2010 tren yang terjadi terhadap rerata nilai AOT adalah penurunan, hal ini dapat disebabkan karena pengurangan jumlah kendaraan bermotor bukan umum dari 6.232 menjadi 4.775 unit dan disahkannya beberapa peraturan daerah seperti Peraturan Daerah Kota Nomor 2 Tahun 2005 tentang Izin Perencana Bangunan Gedung dan Nomor 3 Tahun 2008 tentang Pengendalian Pencemaran Udara. Tahun 2010 hingga 2011 terjadi peningkatan nilai rerata AOT yang signifikan karena Peraturan Daerah Kota Surabaya Nomor 1 Tahun 2010 tentang Penyelenggaraan Usaha Di Bidang Perdagangan dan Perindustrian, Nomor 7 Tahun 2010 tentang Penyerahan Prasarana, Sarana dan Utilitas Pada Kawasan Industri, Perdagangan, Perumahan dan Permukiman, dan Rencana Tata Ruang Wilayah Kota Surabaya Tahun 2010-2030 yang menyebabkan terjadinya peningkatan produksi industri dan dibuktikan dengan adanya peningkatan jumlah daya listrik yang terpasang yaitu sebesar 1.044.164 menjadi 1.152.794 serta adanya peningkatan jumlah kendaraan bermotor bukan umum dari 4.775 menjadi 6.585 unit juga menjadi alasan kondisi AOT yang demikian. Tahun 2011 hingga 2013 terjadi penurunan nilai rerata AOT disebabkan oleh adanya Peraturan Daerah Kota Surabaya Nomor 1 Tahun 2011 tentang Retribusi Pengujian Kendaraan Bermotor dan mengakibatkan penurunan jumlah kendaraan bermotor bukan umum dari 6.585 menjadi 5.676 unit.

Perkembangan yang terjadi di kota Surabaya setelah tahun 2013 adalah peningkatan nilai rerata AOT yang dapat diasumsikan merupakan hasil dari peningkatan jumlah kendaraan bermotor karena masyarakat telah beradaptasi dengan regulasi yang telah ditetapkan sebelumnya yaitu Perda No 1 
Tahun 2011 tentang Retribusi Pengujian Kendaraan Bermotor. Selain itu juga, hasil dari beberapa perda yang memudahkan investor dan peningkatan produksi hasil industri menyebabkan dampak yang signifikan terhadap peningkatan nilai rerata AOT. Setelah menelaah tren permasalahan lingkungan yang terjadi pada tahun 2013 hingga 2015, pemerintah mengupayakan membuat regulasi baru untuk menangani permasalahan ini diantaranya yaitu regulasi pengembangan kawasan usaha dengan konsep superblok atau bangunan multifungsi untuk mengantisipasi membeludaknya perkembangan bisnis di kawasan-kawasan pusat industri, penataan business center yang dikolaborasikan dengan rencana pengembangan kota, program relokasi secara bertahap industri yang berdiri di kawasan yang bukan peruntukannya untuk menghindari dampak buruk aktivitas industri. Selain regulasi umum tersebut, terdapat beberapa tata aturan baru yang diterapkan seperti diwajibkannya kawasan industri untuk membuat buffer zone (kawasan penyangga industri) berupa penyediaan ruang terbuka hijau, menyediakan fasilitas dan utilitas umum, serta memperbaiki sistem instalasi pengolah air limbah (IPAL).

\section{KESIMPULAN}

Tujuan dari penelitian ini adalah untuk mengkaji dan menilai hubungan antara PDRB dengan AOT di DKI Jakarta, Semarang, dan Surabaya menggunakan pendekatan perubahan persentase kontribusi tiap sektor penyumbang PDRB dan perubahan penggunaan lahan. Kami melakukan evaluasi hubungan pada tahun 2005-2015 menggunakan data statistik PDRB tiap kota dengan nilai AOT hasil perekaman citra yang kemudian dinilai dengan analisis regresi.

Kami menemukan bahwa variabel PDRB berkorelasi dengan variabel AOT dengan kekuatan hubungan yang relatif berdasarkan kondisi perkembangan perekonomian serta fisik lahan yang diperuntukan untuk kegiatan industri yang diasumsikan berkontribusi besar terhadap konsentrasi polusi udara di lingkungan. Hasil statistik menunjukkan bahwa bentuk hubungan PDRB terhadap AOT pada ketiga kota besar di indonesia adalah polynomial orde 3 dengan sifat hubungan positif pada DKI Jakarta dan Kota Semarang serta negatif pada Kota Surabaya. Nilai koefisien determinasi $\left(\mathrm{R}^{2}\right)$ tertinggi yang kami dapatkan untuk DKI Jakarta sebesar 0.5223, Kota Semarang sebesar 0.7074, dan Kota Surabaya sebesar 0,414. Nilai tersebut berkaitan dengan kondisi perindustrian tiap kota yang diteliti.

Berdasarkan teori EKC dari pendekatan persentase PDRB maupun perubahan penggunaan lahan industri, ketiga kota yang diteliti memiliki posisi yang berbeda. DKI Jakarta berada pada tahap industrial dibuktikan dengan adanya peningkatan AOT dan pertambahan PDRB, serta peningkatan kawasan industri di DKI Jakarta yang mengalami ekspansi secara spasial. Kota Semarang memiliki PDRB yang didominasi dari kontribusi industri yang cukup besar (Tabel 6) dengan perluasan kawasan industri yang cukup cepat hingga mencapat $1.6 \mathrm{kali}$ lipat luas sebelumnya selama 2005-2015 sehingga dapat disimpulkan bahwa Kota Semarang berada pada tahap pre-industrial. Kota Surabaya berada pada tahap postindustrial karena meskipun peningkatan persentase kontribusi dari sektor industri meningkat, namun berbanding terbalik dengan besarnya polusi udara yang dalam hal ini diasumsikan berasal dari penerapan regulasi dalam manajemen lingkungan.

\section{UCAPAN TERIMA KASIH}

Penulis mengucapkan terima kasih kepada $\mathrm{Bu}$ Wirastuti Widyatmanti atas segala dukungan serta masukannya sehingga penulis dapat menyelesaikan penelitian ini dengan baik; pihak NASA yang telah menyediakan data Citra MODIS level 3 (MYD09CMA) dan BPS yang telah mempublikasikan data statistik pertumbuhan ekonomi DKI Jakarta, Semarang, dan Surabaya; serta seluruh reviewer yang telah memberikan masukan dalam proses pembuatan tulisan ini.

\section{DAFTAR PUSTAKA}


Price Waterhouse Cooper (PwC). The World in 2050: PwC. (https://www.pwc.com/gx/en/issues/ec onomy/the-world-in-2050.html di akses pada 21 Desember 2017).

Stern, 1996. Economic Growth and Environmental Degradation: The Environmental Kuznets Curve and Sustainable Development. World Development. Vol. 24, No. 7, pp. 1151-1160.

Grossman, G. M., dan Krueger A. B. 1994. Environmental Impact of a North American Free Trade Agreement. USMexico Free Trade Agreement. Cambridge: MIT Press.

Cropper, M., dan Griff X. C. 1994. The Interaction of Population Growth and Environmental Quality. American Economic Review. 254.

Lou, Y. 2014. Relationship between Air Pollutants and Economic Development of the Provincial Capital Cities in China during the Past Decade. Plos One. 8.

NASA. Aerosol Optical Thickness. (http://daac.gsfc.nasa.gov/PIP/shtml/ae rosol_optical_thickness_or_depth.shtm 1 diakses pada tanggal 26 November 2107).

Mason, R., dan Timothy S. 2003. The Cost of Uncoordinated Regulation. European Economic Review. 143-167.

Pemerintah Daerah DKI Jakarta. Data Jumlah Perusahaan dan Tenaga Kerja Industri Besar dan Sedang Menurut Klasifikasi Industri di DKI Jakarta Tahun 2011.

(http://data.jakarta.go.id/dataset/datajumlah-perusahaan-dan-tenaga-kerjaindustri-besar-dan-sedang-dkijakarta/resource/c5f485d1-c08a-434e97d9-14645bd94167 diakses pada tanggal 11 November 2017)

Tomasi, C., Sandro F., dan Alexander Kokhanovsky. 2106. Atmospheric Aerosols: Life Cycles and Effects on Air Quality and Climate. Weinheim,
Germany: Wiley-VCH Verlag GmbH \& Co.

Purwanto, L M F. 2005. Kota Kolonial Lama Semarang. Tinjauan Umum Sejarah Perkembangan Arsitektur Kota. Dimensi Teknik Arsitektur. 27-33.

Badan Pusat Statistik. Statistik Industri Besar dan Sedang Kota Semarang Tahun 2009. Semarang: Badan Pusat Statistik.

Ansuategi, A, E., dan Barbier B., dan Perrings C. A. 1998. The Environmental Kuznets Curve. Theory and Implementation of Economic Models for Sustainable Developmen. Kluwer: Dordrecht.

Arrow, K. 1995. Economic Growth, Carrying Capacity, and the Environment. Science. 268: 520-521.

Ekins, P. 1997. The Kuznets Curve for The Environment and Economic Growth: Examining The Evidence. Environment and Planning A. 29: 805830.

Pearson, P J G. 1994. Energy, Externalities, And Environmental Quality: Will Development Cure The Ills It Creates. Energy Studies Review.6.199-216.

Stern, D. I., Common M. S., dan Barbier, E. B. 1996. Economic Growth and Environmental Degradation: The Environmental Kuznets Curve and Sustainable Development. World Development. 24. 1151-1160.

Perman, R., dan Stern, D. I. 2003. Evidence from Panel Unit Root and Cointegration Tests that The Environmental Kuznets Curve Does Not Exist. Australian Journal of Agricultural and Resource Economics. Vol 47.

Junaidi, M. 2015. Pengembangan Kawasan Industri Dalam Memaksimalkan Pendapatan Asli Daerah Di Kota Semarang. Konsep Pembangunan Berkelanjutan. 57 - 68. 
